\title{
DAKWAH PEMBERDAYAAN MASYARAKAT DESA DANASARI KECAMATAN PEMALANG KABUPATEN PEMALANG
}

\author{
Purnama Rozak, Hafiedh Hasan, Sugarno, \\ Srifariyati, Afsya Septa Nugraha \\ Sekolah Tinggi Ilmu Tarbiyah (STIT) Pemalang
}

\begin{abstract}
The success of the development of a nation is determined by the Human Development Index (HDI). International scale parameter indicates the level of development of human resources emphasizes on three areas: education, health, and income per capita. The various dimensions of community development was a collective responsibility to make it happen. One way to do is through the proselytizing activities of community empowerment. This is as done in the village of Pemalang district, Danasari that has HDI levels is low compared than other villages. Community development in this village was done by taking three primary focus , they are the field of economics, health, and education and religion.

Keberhasilan pembangunan suatu bangsa ditentukan oleh Human Development Indeks (HDI). Parameter berskala internsional ini menunjukkan tingkat pengembangan sumber daya manusia yang menitiberatkan pada tiga bidang yaitu pendidikan, kesehatan, dan pendapatan perkapita. Pengembangan masyarakat yang berbagai dimensi tadi merupakan tanggung jawab bersama untuk mewujudkannya. Salah satu cara yang dapat dilakukan adalah melalui kegiatan dakwah pemberdayaan masyarakat. Hal ini sebagaimana dilakukan di Desa Danasari Kabupaten Pemalang yang memiliki tingkat HDI yang rendah dibandingkan desa lainnya. Pemberdayaan masyarakat di desa ini dilakukan dengan mengambil tiga fokus utama yaitu bidang ekonomi, bidang kesehatan, dan pendidikan dan keagamaan. Potensi yang ada perlu diberdayakan secara bersama dengan tujuan pencapaian perbaikan kehidupan masyarakat desa Danasari.
\end{abstract}

Keywords: Propaganda, Community Empowerment. 


\section{A. Pendahuluan}

Wacana diskursus pembangunan modern, keberhasilan pembangunan suatu bangsa ditentukan oleh beberapa ukuran atau parameter yang telah disepakati bersama. Adalah Human Development Indeks (HDI) yang dijadikan sebagai parameter ukur tersebut yang mana menyangkut tiga hal yaitu tingkat pendidikan penduduk, tingkat kesehatan penduduk, dan belanja perkapita penduduk.

Masalah kemiskinan masyarakat di Kabupaten Pemalang diketahui dari besarnya nilai indek pembangunan manusia (IPM). Indeks Pembangunan Manusia (IPM) merupakan salah satu indikator agregat dari capaian peningkatan kesejahteraan dalam pembangunan Kabupaten Pemalang. IPM Kabupaten Pemalang tahun 2009 sebesar 69,02 meningkat dari tahun 2008 sebesar 68,38. Kondisi tersebut masih lebih rendah daripada rata-rata Jawa Tengah sebesar 72,10 dan menduduki peringkat 34 dari 35 kabupaten/kota. Peringkat tersebut tetap bila dibandingkan dengan keadaan tahun 2008. Indeks Pembangunan Manusia Kabupaten Pemalang tahun pada 2009 cenderung mengalami peningkatan dalam empat tahun terakhir, dari tahun 2006 sebesar 67,40 meningkat menjadi sebesar 69,02 pada tahun 2009, atau meningkat sebesar 1,62 selama empat tahun, atau rata-rata setiap tahun meningkat sebesar 0,40.

Jika dibandingkan dengan Kabupaten disekitarnya IPM Kabupaten Pemalang lebih tinggi dari Kabupaten Brebes, namun masih dibawah kabupaten/kota yang lain dan rata-rata Provinsi Jawa Tengah $(72,10)$. Data selengkapnya dapat dilihat pada tabel berikut ini:

Tabel 1.1

Indeks Pembangunan Manusia Di Kabupaten Pemalang Dan Wilayah Sekitarnya Tahun 2006 - 2009

\begin{tabular}{lcccccc}
\hline \multirow{2}{*}{ Wilayah } & \multicolumn{3}{c}{$\begin{array}{c}\text { Indeks Pembangunan } \\
\text { Manusia (IPM) }\end{array}$} & \multicolumn{3}{c}{$\begin{array}{c}\text { Ranking se } \\
\text { Jawa Tengah }\end{array}$} \\
\cline { 2 - 7 } & $\mathbf{2 0 0 6}$ & $\mathbf{2 0 0 7}$ & $\mathbf{2 0 0 8}$ & $\mathbf{2 0 0 9}$ & $\begin{array}{c}\mathbf{2 0 0} \\
\mathbf{8}\end{array}$ & $\mathbf{2 0 0 9}$ \\
\hline 1. Kabupaten Brebes & 65,90 & 66,57 & 67,08 & 67,69 & 35 & 35 \\
\hline 2. Kabupaten Tegal & 67,80 & 68,83 & 69,54 & 70,08 & 30 & 29 \\
\hline 3. Kabupaten Pekalongan & 69,40 & 69,69 & 70,31 & 70,83 & 23 & 23 \\
\hline 4. Kabupaten Pemalang & 67,40 & 67,89 & 68,38 & 69,02 & 34 & 34 \\
\hline 5. Kota Tegal & 72,40 & 72,72 & 73,20 & 73,63 & 8 & 8 \\
\hline 6. Kota Pekalongan & 72,50 & 73,10 & 73,49 & 74,01 & 5 & 5 \\
\hline \multicolumn{1}{c}{ Jawa Tengah } & 70,30 & 70,92 & 71,60 & 72,10 & - & - \\
\hline
\end{tabular}

Sumber : IPM Provinsi Jawa Tengah tahun 2006-2009. 
Jika dilihat dari komponen pembentuk IPM, Usia Harapan Hidup (UHH) Kabupaten Pemalang tahun 2007 - 2009 mengalami peningkatan, dari 66,97 tahun menjadi 67,46 tahun, hal ini menunjukkan derajat kesehatan penduduk di Kabupaten Pemalang meningkat. Rata-rata kenaikan UHH bertambah sebesar 0,50 tahun. Angka Melek Huruf (AMH) tahun 2007 sebesar 87,34\% meningkat menjadi 87,75\% ditahun 2009 atau meningkat sebesar 0,41 . Sementara untuk rata-rata lama sekolah yakni 6,1 tahun ditahun 2007 menjadi sebesar 6,49 tahun atau secara rata-rata penduduk Kabupaten Pemalang usia 15 tahun keatas berpendidikan setingkat kelas satu SMP (kelas 7). Secara umum daya beli penduduk Kabupaten Pemalang tahun 2009 tidak mengalami peningkatan berarti, bila dilihat dari sisi pengeluaran per kapita, yakni dari Rp. 628.000,00 menjadi Rp.634.260,00. Untuk capaian daya beli masyarakat/penduduk disuatu wilayah, angka ideal setiap tahun mengalami penyesuaian sesuai dengan kondisi riel ekonomi. Data Selengkapnya dapat dilihat pada tabel berikut :

Tabel 1.2

Perbandingan Pembentuk IPM Kabupaten Pemalang dan Wilayah Sekitarnya Tahun 2007 - 2009

\begin{tabular}{|c|c|c|c|c|c|c|c|c|c|c|c|c|c|}
\hline \multirow[t]{2}{*}{ No. } & \multirow[t]{2}{*}{ ilayah } & \multicolumn{3}{|c|}{$\begin{array}{l}\text { Angka Harapan } \\
\text { Hidup (Th) }\end{array}$} & \multicolumn{3}{|c|}{$\begin{array}{c}\text { Angka Melek } \\
\text { Huruf(\%) }\end{array}$} & \multicolumn{3}{|c|}{$\begin{array}{l}\text { Rata-rata lama } \\
\text { sekolah (th) }\end{array}$} & \multicolumn{3}{|c|}{$\begin{array}{c}\text { Rata-Rata } \\
\text { Pengeluaran Per } \\
\text { Kapita (ribu Rp) }\end{array}$} \\
\hline & & 2007 & 8 & 09 & 2007 & 2008 & 2009 & 2007 & 2008 & 2009 & 2007 & 2008 & 2009 \\
\hline 1. & &, 75 & 8 & 37 & 84,85 & 84 & 85,21 & 5,50 & 50 & 5,62 & 5,37 & 9,64 & 33,23 \\
\hline 2. & & 7,86 & 68,19 & 68,49 & 88,46 & 89,09 & 89,21 & 6,20 & 6,24 & 6,42 & 629,67 & 634,24 & 637,09 \\
\hline 3. & & 68,13 & 68,45 & 68,37 & 89,39 & 89,94 & 90,60 & 6,50 & 6,50 & 6,66 & 633,17 & 637,47 & 38,79 \\
\hline 4. & & 7 & 67,24 & 46 & 87,34 & 87,34 & 87,75 & 6,10 & 0 & 6,49 & 8,00 & 632,39 & 34,26 \\
\hline 5. & . & 68,14 & 68,37 & 68,56 & 94,87 & 94,87 & 94,88 & 0,00 & 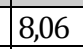 & 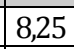 & 641,73 & 30 & 48,66 \\
\hline 6. & ngan & 69,80 & 70,01 & 70,16 & 95,37 & 95,37 & 95,48 & 8,52 & 52 & 8,66 & 628,79 & 632,38 & 36,28 \\
\hline & $\begin{array}{l}\text { Jawa } \\
\text { Tengah }\end{array}$ & 70,90 & 71,10 & 71,25 & 88,62 & 89,24 & 89,46 & 6,80 & 6,86 & 7,07 & 528.5 & 0633 & \\
\hline
\end{tabular}

Sumber : Susenas tahun $2007-2009$

Jumlah penduduk miskin yang cukup besar, menjadi salah satu masalah dalam pembangunan di Kabupaten Pemalang, dengan garis kemiskinan (2004) sebesar Rp. 107.837 maka jumlah penduduk miskin diketahui sebanyak 371.500 jiwa $(26,91 \%)$ dari jumlah penduduk. 
Sedangkan banyaknya keluarga di Kabupaten Pemalang (2004) sebanyak 307.348 KK, secara rinci diketahui keluarga yang termasuk kategori Pra KS sebanyak 89.112 (28,99\%); KS I sebanyak 85.690 (27,88\%); KS II sebanyak $87.218(28,38 \%)$; KS III sebanyak $41.662(13,56 \%)$ dan KS III plus sebesar 3.666 (1,19\%) (Jawa Tengah Dalam Angka, 2005). Masalah kemiskinan sebagaian besar dialami oleh masyarakat perdesaan, terutama penduduk yang tinggal di desa tertinggal, pinggir hutan/perkebunan dan desa pantai. Salah satu desa tertinggal yang penduduknya masih dibawah garis kemiskinan di Kabupaten Pemalang adalah desa Danasari.

Untuk mengantisipasi masalah tersebut, maka perlu dilakukan pengembangan dakwah Islam yang diorganisir secara rapi dan profesional, dengan menggali, memanfaatkan, menggerakkan dan memberdayakan potensi-potensi SDM yang ada di masyarakat, potensi lembaga-lembaga dakwah Islam yang tumbuh di masyarakat, serta potensi-potensi lainnya yang mendukung tercapainya pengembangan ekonomi umat di Kabupaten Pemalang Propinsi Jawa Tengah.

Dakwah di samping berarti tabligh (menyampaikan ajaran), juga berarti mengajak orang untuk bersama-sama melakukan kerja nyata (dakwah bi al-hal) dalam bidang-bidang yang berjangkauan luas menyangkut peningkatan kualitas kebutuhan-kebutuhan hidup dan kehidupan masyarakat dalam berbagai seginya. Kedua macam bentuk dakwah ini perlu dilaksanakan secara bersama-sama guna mengarahkan kuantitas umat Islam menuju ke kualitas keberagamaan dan kehidupan mereka. ${ }^{1}$

Selama ini kegiatan dakwah masih menghadapi berbagai tantangan, yaitu: (1) meningkatnya kerusuhan yang membawa simbolsimbol agama; (2) gerakan dakwah kurang terencana dan kurang terkoordinasi; (3) gerakan dakwah belum sepenuhnya memadai, kurang mampu mengidentifikasi dan menjawab kebutuhan-kebutuhan aktual umat; (4) ada kecenderungan menampilkan wajah Islam ke dalam potret diri yang menakutkan; (5) dakwah lebih banyak dilakukan dalam bentuk lisan, sementara sangat kecil porsinya dalam bentuk dakwah bi al-hal (tindakan nyata) yang menyentuh kebutuhan riil masyarakat; dan (6) kurang ada evaluasi terhadap kegiatan dakwah, sehingga tidak banyak diketahui kegagalan, kelemahan dan keberhasilannya. ${ }^{2}$

Dalam konteks pembangunan nasional,saat ini masyarakat sudah memasuki era industri dan informasi yang sarat akan muatan positif dan

${ }^{1}$ Ahmad, Amin., Dakwah Islam Sebagai Ilmu, Sebuah Kajian Epistemologi dan Struktur Keilmuan Dakwah, (Fak. Dakwah IAIN Sumut, Medan, 1996), hal 184

2Ibid, 215 
dampak negatifnya. Dalam memasuki era tersebut, masyarakat Islam Pemalang memerlukan kesiapan-kesiapan tertentu, baik segi kualitas SDM, ketrampilan dan keahlian, kesiapan mental-spiritual, maupun kesaipan sektor ekonomi sebagai masyarakat yang religius. Kegiatan dakwah Islam akan menjadi kurang bermakna bila belum mampu menjawab berbagai tantangan tersebut ${ }^{3}$

Dengan demikian, dakwah betul-betul mampu menyentuh pada pengembangan masyarakat dalam arti, tidak sekedar berorientasi pada ukhrowi, tetapi juga duniawi. Hal tersebut relevan dengan fungsi dakwah yang sebenarnya, sebagai: (1) penjelasan upaya mentrasformasikan nilainilai kebenaran dan memberi penjelasan manhaj dalam upaya mewujudkan ajaran Islam ke dalam tatanan khoiru umah, (2) upaya transformasi iman ke dalam amal shalih jamaah, dan (3) upaya membangun dan mengembalikan manusia pada fitrahnya untuk meluruskan tujuan hidup manusia dan menegakkan fungsi khalifah manusia di bumi untuk memakmurkan alam semesta, agar damai dalam menggapai kehidupan ${ }^{4}$

\section{B. Metodologi Pengabdian}

Pengabdian Masyarakat ini bertujuan untuk Tujuan kegiatan ini adalah: Mendeskripsikan desa Danasari dilihat dari letak geografis dan penduduknya. Mendeskripsikan proses kegiatan dakwah di desa Danasari. Pelaksanaan program ini meliputi kegiatan studi awal, diskusi dan sosialisasi, workshop dan pelatihan serta Pemberian Bibit Jahe Kepada Masyarakat Desa Danasari dan konsultasi pemeliharaan Kegiatan ini dilaksanakan di desa Danasariselama4 bulan dari bulan September sampai dengan bulan Desember2014 menggunakan metode PAR, melalui observasi, diskusi dan dilanjutkan dengan workshop dan pelatihan.

\section{Dakwah}

\section{Pengertian Dakwah}

Dalam proses pengertian yang integralistik, dakwah merupakan proses yang berkesinambungan yang ditangani oleh para pengemban dakwah dalam rangka mengubah sasaran dakwah agar bersedia masuk ke

3Ibid 186

4Sulthon, M, Menjawab Tantangan Zaman: Disain Ilmu Dakwah, Kajian Ontologis, Epistemologis, dan Aksiologis, (Pustakan Pelajar, Jogyakarta: 2003), hal 123 
jalan Allah, dan secara bertahap menuju perkehidupan yang Islami. Suatu proses yang berkenambungan adalah suatu proses yang bukan insidental atau kebetulan, melainkan benar-benar direncanakan, dilaksanakan, dan dievaluasi secara terus menerus oleh para pengemban dakwah dalam rangka mengubah perilaku sasaran dakwah sesuai dengan tujuan-tujuan yang telah dirumuskan.

Sudah bukan waktunya lagi, dakwah dilakukan asal jalan, tanpa sebuah perencanaan yang matang, baik yang menyangkut materinya, tenaga pelaksanya, ataupun metode yang dipergunakannya. Memang benar, sudah menjadi sunnatullah bahwa yang hak akan menghancurkan yang batil (QS. Al-Isra: 81), tetapi sunnatullah ini berkaitan dengan sunnatullah yang lain, yaitu bahwasannya Allah SWT sangat mencintai dan meridhai kebenaran yang diperjuangkan dalam sebuah barisan yang rapi dan teratur. (QS. Ash-Shaf: 4)

\section{Kewajiban Dakwah}

Bagi seorang muslim, dakwah merupakan kewajiban yang tidak bisa di tawar-tawar lagi. Kewajiban dakwah merupakan sesuatu yang bersifat conditio sinequanon, tidak mungkin dihindarkan dari kehidupannya. Dakwah karenanya melekat erat bersamaan dengan pengakuan dirinya sebagai seorang yang mengidentifikasikan diri seorang penganut Islam, sehingga orang yang mengaku dirinya sebagai seorang muslim maka secara otomatis pula dia itu menjadi juru dakwah.

Dakwah merupakan bagian yang sangat penting dalam kehidupan seorang muslim bahkan tidak berlebihan kiranya apabila kita katakan bahwa tidak sempurna bahkan sulit kita katakan seseorang itu muslim apabila dia menghindari atau membutakan matanya dari tanggung jawabnya sebagai juru dakwah. ${ }^{5}$ Selain itu dakwah merupakan kewajiban syar'I, berdasarkan Q.S Ali Imran: 10 yang artinya:

Dan hendaklah ada diantara kamu segolongan umat yang menyeru kepada kebajikan, menyuruh kepada yang ma'ruf dan mencegah dari yang mungkar, merekalah orang-orang yangberuntung". (Ali Imran: 10)

\section{Tujuan Dakwah}

Dakwah mempunyai tujuan yakni tujuan secara umum dan tujuan secara khusus.

5Toto Tasmara, Komunikasi Dakwah, (Jakarta: Gaya Media Pratama,1977), hal 32-33 
a. Tujuan umum dakwah (major obyektive)

Tujuan umum dakwah merupakan sesuatu yang hendak dicapai dalam seluruh aktifitas dakwah.

b. Tujuan khusus dakwah sebagai terjemahan dari major objektive yaitu:

1) Mengajak umat manusia yang sudah memeluk agama Islam untuk selalu meningkatkan takwanya kepada Allah SWT. Artinya mereka diharapkaagar senantiasa mengerjakan segala perintah Allah dan selalu meninggalkan larangan-Nya.

2) Membina mental agama (Islam) bagi kaum yang masih muallaf.

3) Mengajak umat manusia yang belum beriman kepada Allah (memeluk agama Islam).

4) Mendidik dan mengajar anak-anak agar tidak menyimpang dari fitrahnya.

\section{Pemberdayaan Masyarakat}

\section{Pengertian Pemberdayaan}

Menurut Moelyarto dalam Wahyono dkk. (2001) pengertian pemberdayaan masyarakat mengacu pada kata "empowerment" yaitu, sebagai upaya untuk mengaktualisasikan potensi yang sudah dimiliki olah masyarakat. ${ }^{6}$

Kartasasmita dalam Surochiem (2001) menyatakan bahwa pemberdayaan masyarakat merupakan sebuah konsep pembangunan ekonomi yang merangkum nilai-nilai sosial. Konsep ini mencerminkan paradigma baru pembangunan, yaitu people centered, participatory, empowering and sustainable.Konsep ini tidak hanya semata-mata memenuhi kebutuhan dasar (basic needs) dan mencegah proses kemiskinan lebih lanjut (safety net) dimana upaya yang dilakukan akan diarahkan langsung kepada akar persoalannya, yaitu meningkatkan kemampuan masyarakat.7 Bagian yang tertinggal dalam masyarakat harus ditingkatkan kemampuannya dengan mengembangkan dan mendinamiskan potensinya, pendek kata memberdayakannya. Dengan demikian rakyat dan lingkungannya mampu secara partisipatif menghasilkan dan menumbuhkan nilai tambah ekonomis. Rakyat miskin atau yang berada pada posisi belum termanfaatkan secara penuh

${ }^{6}$ Ari Wahyono, dkk. Pemberdayaan Masyarakat Nelayan, Yogyakarta: Media Pressindo, 2001

${ }^{7}$ Surochiem, Dimensi-dimensi Penting Monitoring Pelaksanaan Program Pemberdayaan dan Partisipasi pada Masyarakat Pesisir. Jurnal, 2001 
potensinya akan meningkat bukan hanya ekonominya, tetapi juga harkat, martabat, rasa percaya diri dan harga dirinya.

Dengan demikian Empowerment atau pemberdayaan secara singkat dapat diartikan sebagai upaya untuk memberikan kesempatan dan kemampuan kepada kelompok masyarakat untuk berpartisipasi, bernegoisasi, mempengaruhi, dan mengendalikan kelembagaan masyarakat secara bertanggung jawab demi perbaikan kehidupannya. Pemberdayaan juga diartikan sebagai upaya untuk memberikan daya (empowerment) atau kekuatan (strength) kepada masyarakat.

\section{Prinsip Pemberdayaan}

Pada dasarnya, pemberdayaan masyarakat nelayan bertujuan untuk mencapai kesejahteraan sosial, dan hal ini menjadi basis membangun fondasi civil society di kawasan pesisir. Untuk mencapai tujuan ini diperlukan dukungan kualitas sumberdaya manusia (SDM), kapasitas dan fungsi kelembagaan social ekonomi yang optimal dalam kehidupan warga, serta tingkat partisipasi politik warga yang tinggi. ${ }^{8}$ Oleh karena itu, diperlukan perencanaan yang komprehensif dan tujuan yang terukur, yang pencapaiannya dilakukan secara bertahap, dengan memperhatikan kemampuan sumber daya pembangunan yang dimiliki oleh masyarakat lokal. Tujuan pemberdayaan di atas dapat tercapai dengan baik, jika terjadi interaksi dialetika yang konstruktif, antara Negara, masyarakat dan kebijakan atau strategi pengelolaan sumberdaya sosial, ekonomi dan lingkungan. Beberapa dasar pemikiran filosofis yang harus dipertimbangkan dalam kegiatan pemberdayaan masyarakat nelayan adalah sebagai berikut 9

a. Potensi sumberdaya alam yang ada di kawasan pesisir adalah karunia Allah SWT yang harus dijaga kelestariannya.

b. Pengelolaan potensi sumberdaya alam pesisir dan laut harus dilaksanakan oleh masyarakat pengguna berdasarkan sikap hati-hati.

c. Negara bertanggungjawab terhadap masa depan kehidupan warganya dan menjamin perwujudan hak-hak warga terhadap akses sumberdaya ekonomi dan lingkungan sebagai upaya menjaga kelangsungan hidup masyarakat di kawasan pesisir.

d. Negara, masyarakat dan pihak lain bertanggung jawab untuk melindungi kelestarian sumber daya alam dari berbagai ancaman

${ }^{8}$ Kusnadi, Strategi Hidup Masyarakat Nelayan, Yogyakarta : LkiS, 2007

9'bid 
e. Kawasan pesisir merupakan "halaman depan" Negara Kepulauan Republik Indonesia, sehingga pembangunan kawasan pesisir harus ditujukan untuk memperkuat ketahanan bangsa (masyarakat nelayan) menghadapi berbagai ancaman yang datang dari arah laut. Kerapuhan sosial ekonomi masyarakat nelayan berpotensi menjadi sumber ketidakstabilan politik kawasan.

\section{Tujuan Pemberdayaan}

Tujuan yang ingin dicapai dari pemberdayaan masyarakat adalah untuk membentuk individu dan masyarakat menjadi mandiri. Kemandirian tersebut meliputi kemandirian berpikir, bertindak dan mengendalikan apa yang mereka lakukan. Kemandirian masyarakat merupakan suatu kondisi yang dialami oleh masyarakat yang ditandai dengan kemampuan memikirkan, memutuskan serta melakukan sesuatu yang dipandang tepat demi mencapai pemecahan masalah yang dihadapi dengan mempergunakan daya/kemampuan yang dimiliki.

\section{Aspek Pemberdayaan}

Ditinjau dari lingkup dan objek pemberdayaan mencakup beberapa aspek, yaitu:

a. Peningkatan kepemilikan aset (Sumber daya fisik dan finansial) serta kemampuan secara individual maupun kelompok untuk memanfaatkan aset tersebut demi perbaikan kehidupan mereka.

b. Hubungan antar individu dan kelompok, kaitannya dengan pemilikan aset dan kemampuan memanfaatkannya.

c. Pemberdayaan dan reformasi kelembagaan.

d. Pengembangan jejaring dan kemitraan-kerja, baik di tingkat lokal, regional maupun global.

\section{Tahap-tahap Pemberdayaan}

Pemberdayaan tidak bersifat selamanya, melainkan sampai target masyarakat mampu untuk mandiri, dan kemudian dilepas untuk mandiri, meski dari jauh dijaga agar tidak jatuh lagi, berarti pemberdayaan melalui suatu masa proses belajar, hingga mencapai status mandiri. Meskipun demikian dalam rangka menjaga kemandirian tersebut tetap dilakukan pemeliharaan semangat, kondisi, dan kemampuan secara terus menerus supaya tidak mengalami kemunduran lagi.

Tahap-tahap yang harus dilalui dalam proses belajar adalah : 
a. Tahap penyadaran dan pembentukan perilaku menuju perilaku sadar dan peduli sehingga merasa membutuhkan peningkatan kapasitas diri. Tahap transformasi kemampuan berupa wawasan pengetahuan, kecakapan keterampilan agar terbuka wawasan dan memberikan keterampilan dasar sehingga dapat mengambil peran di dalam pembangunan.

b. Tahap peningkatan kemampuan intelektual, kecakapan keterampilan sehingga terbentuklah inisiatif dan kemampuan inovatif untuk mengantarkan kepada kemandirian.

\section{Proses Pemberdayaan}

Proses pemberdayaan mengandung dua kecenderungan. Pertama, proses pemberdayaan yang menekankan pada proses memberikan atau mengalihkan sebagian kekuatan, kekuasaan atau kemampuan kepada masyarakat agar individu lebih berdaya.Kecenderungan pertama tersebut dapat disebut sebagai kecenderungan primer dari makna pemberdayaan. Sedangkan kecenderungan kedua atau kecenderungan sekunder menekankan pada proses menstimulasi, mendorong atau memotivasi individu agar mempunyai kemampuan atau keberdayaan untuk menentukan apa yang menjadi pilihan hidupnya melalui proses dialog".

ciri-ciri warga masyarakat berdaya yaitu:

a. Mampu memahami diri dan potensinya, mampu merencanakan (mengantisipasi kondisi perubahan ke depan).

b. Mampu mengarahkan dirinya sendiri.

c. Memiliki kekuatan untuk berunding.

d. Memiliki bargaining power yang memadai dalam melakukan kerjasama yang saling menguntungkan.

e. Bertanggungjawab atas tindakannya.

\section{Unsur-unsur Pemberdayaan}

Upaya pemberdayaan masyarakat perlu memperhatikan empat unsur pokok, yaitu:

a. Aksebilitas informasi, Kemampuan akses yang diterima oleh masyarakat.

b. Partisipasi atau keterlibatan, menyangkut siapa yang dilibatkan dan bagaimana mereka terlibat dalam keseluruhan proses pembangunan.

c. Akuntabilitas, Pertanggungjawaban publik atas segala kegiatan yang dilakukan dengan mengatasnamakan rakyat. 
d. Kapasitas organisasi local, Kemampuan berkerja sama, mengorganisir warga masyarakat, serta memobilisasi sumber daya untuk memecahkan masalah-masalah yang mereka hadapi.

\section{Metode Pemberdayaan}

Kegiatan pemberdayaan masyarakat merupakan kesatuan proses yang berkelanjutan melalui kegiatan "kaji tindak yang partisipatif" atau dikenal sebagai Participatory Action Research/ PAR.Pengertian PAR tidak hanya melibatkan partisipasi masyarakat, melainkan lebih bernuansa filosofis untuk memberikan kesempatan dan kepercayaan terhadap kemampuan dan kemauan masyarakat untuk melaksanakan pembangunan di wilayahnya sendiri dan bagi kepentingan peningkatan masyarakatnya sendiri sesuai dengan kebutuhan potensi yang mereka miliki, melalui kegiatan aksi dan refleksi yang berkelanjutan.

Di dalam pelaksanaanya, PAR dilaksanakan sebagai berikut;

a. Kegiatan pengumpulan data dasar, dilaksanakan dengan menggabungkan teknik penilaian desa secara cepat (Rapid Rural Appraisal/ RRA) yang dilakukan oleh orang luar dan survai mandiri yang dilakukan sendiri oleh masyarakat melalui Community Self Survei. Dalam Pengabdian ini melalui obseravasi dan forum diskusi.

b. Kegiatan perencanaan kegiatan yang dilakukan melalui kegiatan penilaian partisipatif atau Participatory Rural Appraisal.

c. Kegiatan aksi merupakan 'proses belajar' yang terus menerus dan dilaksanakan dalam bentuk pelatihan yang kait mengait secara berkelanjutan, dengan menggunakan metode pendidikan orang dewasa yang partisipatif (Participatory Training Method).

\section{E. Pemberdayaan Masyarakat Desa Danasari}

\section{Gambaran Umum Lokasi Pengabdian}

Desa Danasarimerupakan salah satu kampung yang berada dalam wilayah administrasi Kecamatan Pemalang Kabupaten Pemalang terletak di pesisir utara Propinsi Jawa Tengah, mempunyai 1928 Kepala Keluarga (KK), 5 (lima) Dusun, 21 (Dua Puluh Tiga) Rukun Tetangga (RT) dan 8 (Delapan) Rukun Warga (RW) dengan luas wilayah 358,435 Ha. Secara geografis, wilayah ini terletak pada $0,5 \mathrm{~m}$ ketinggian tanah dari permukaan laut, dan banyaknya curah hujan $400 \mathrm{~mm} / \mathrm{m}$

Adapun batas-batas wilayah administrasi Desa Danasari adalah sebagai berikut: 
a. Sebelah Utara: Laut Jawa

b. Sebelah Timur: Kali Elon/ Desa Asemdoyong

c. Sebelah Selatan: Wanarejan-Pelutan

d. Sebelah Barat: Widuri

\section{Keadaan Penduduk}

a. Jumlah Penduduk Berdasarkan Jenis Kelamin

Jumlah penduduk Desa Danasari sebanyak 7.518 jiwa terdiri dari 1.928 Kepala Keluarga, 5 Dusun dan 21 Rukun Tetangga (RT), dan 8 Rukun Warga (RW). Laki-laki berjumalah 3.855 jiwa dan perempuan berjumlah 3.663 jiwa

b. Jumlah Penduduk Berdasarkan Struktur Pendidikan

Berdasarkan dari hasil pengamatan dan wawancara di lapangan untuk memperoleh informasi terhadap tingkat pendidikan penduduk Desa Danasari pada kegiatan ini ditemukan bahwa tingkat pendidikan penduduk Desa Danasari bermacam-macam.Sebagaian besar adalah berpendidikan tamat SD.

c. Jumlah Penduduk Berdasarkan Pekerjaan atau Mata Pencaharian Pokok

Pekerjaan atau mata pencarian pokokmasyarakat Danasari bervariasi, dari petani sampai dengan karyawan perusahaan pemerintah. Ternyata pekerjaan atau mata pencarian pokok masyarakat Danasari673 jiwa (19,08\%)terdiri dari Petani dan 1.135 jiwa adalah buruh tani $(32,17 \%)$, selebihnya kurang dari separuhnya adalah nelayan, Pegawai Negeri Sipil, karyawan swasta, Pertukangan, pemulung, pedagang, TNI, POLRI, Pensiunan, Pengusaha Kecil dan Menengah, dan Jasa. Dari hasil penelusuran, ternyata diantara mereka lebih banyak sebagai Petani dan buruh tani.

d. Jumlah Penduduk Berdasarkan Agama

Kepercayaan dan Agama yang dianut oleh penduduk Desa Danasari $100 \%$ adalahberagama Islam.

\section{F. Aspek Pemberdayaan Masyarakat Desa Danasari}

Upaya Dakwah pemberdayaan masyarakat Danasari berdasarkan pada potensi masyarakatnya, dan permasalahan yang ditemui di lokasi setelah diadakan observasi, dialog dan wawancara dapat ditinjau dari beberapa aspek antara lain: 


\section{Ekonomi}

Dilihat dari status sosial dan ekonomi masyarakat Danasari 51, 25\% masyarakatnya bermata pencaharian pokoknya sebagai petani. Dari Mereka banyak yang memiliki lahan yang masih belum secara maksimal dimanfaatkan, maka motivasi pemanfaatan lahan ini perlu dikembangkan.

2. Kesehatan

Kegiatan kesehatan masyarakat Desa Danasari berpusat di Puskesmas dan Posyandu. Masing-masing RW ada 1 posyandu, dan berjalan dengan baik.

3. Pendidikan dan Keagamaan

Berdasarkan data di atas, tingkat pendidikan penduduk Danasari yang pernah sekolah SD maupun yang hanya mampu tamat Sekolah Dasar (SD) sebanyak 842 jiwa $(67,436 \%)$. Maka hal ini perlu mendapat perhatian. Sedangkan Kepercayaan dan Agama yang dianut oleh penduduk Desa Danasari (100\%) atau sebanyak 7.518 adalah beragama Islam. Ini adalah potensi yang dapat diberdayakan.

Ruang lingkup kegiatan Dakwah pemberdayaan masyarakat Desa Danasari Kecamatan Pemalang Kabupaten Pemalang ini dapat dikelompokkan menjadi dua bagian, yaitu ruang lingkup wilayah dan ruang lingkup kegiatan yang mengggambarkan tahap-tahap kegiatan yang telah dilaksanakan.

Ruang lingkup wilayah kegiatan meliputi kelompok sasaran masyarakat desa Danasari di wilayah desa Danasari yang terdiri dari Perangkat desa, Ketua RT dan RW, Kader PKK, Tokoh Masyarakat, Perwakilan Pedagang, Petani dan Buruh yang berjumlah 100 orang.

Sedangkan ruang lingkup kegiatan dalam rangka Dakwah pemberdayaan masyarakat desa Danasari Kecamatan Pemalang Kabupaten Pemalang dengan Workshop dan pelatihan yang diawali dengan observasi dan dialog dengan Kepala Desa Danasari, Perangkat desa, dan perwakilan dari Masyarakat Desa Danasari. Kegiatan Workshop dan Pelatihan ini melibatkan instansi dan pihak terkait (stakeholder) yang berhubungan dengan upaya Dakwah Pemberdayaan dan pelayanan kesejahteraan masyarakat, baik dari lembaga pemerintah seperti Kementerian Agama Kab. Pemalang, dan Dinas Pertanian dan kehutanan, Perguruan Tinggi STIT Pemalang, dan masyarakat desa Danasari pada umumnya.

Adapun yang menjadi pokok kegiatan adalah:

1. Studi Awal tentang desa Danasari.

2. Sosialisasi kepada masyarakat desa Danasari. 
3. Workshop dan pelatihan untuk Perangkatdesa, Ketua RT dan RW, Kader PKK, TokohMasyarakat, Guru, Pedagang, PetanidanBuruhdi Desa Danasari.

4. Pemberian Bibit Jahe Kepada Masyarakat Desa Danasari dan konsultasi pemeliharaan.

5. Pelaporan kegiatan

Pelaksanaan program pengabdian masyarakat dengan tema dakwah pemberdayaan masyarakat desa Danasari adalah meliputi kegiatan studi awal, diskusi dan sosialisasi, workshop dan pelatihan, dan pemberian bibit tanaman Jahe kepada masyarakat desa Danasari.

\section{Studi Awal}

Kegiatan ini dilakukan untuk mengetahui gambaran umum dan keadaan penduduk desa Danasari dililihat dari letak geografis, jumlah lakilaki dan perempuan, pendidikan, tingkat sosial ekonomi, dan agamanya. Data ini diperoleh melalui dokumentasi, observasi dan interview yang bersumber dari data primer dan data sekunder. Data primer yaitu data yang langsung berasal dari Kepala Desa Bapak H. Sanuri, S.Ip, perangkat desa Ibu Sri Parihati, dan masyarakat desa Danasari sebagai key informan. Sedangkan data sekunder adalah data yang diambil dari data yang sudah ada berupa kebijakan, petunjuk/pedoman operasional atau standarisasi penyelenggaraan program. Kegiatan ini dilakukan pada bulan September sampai dengan Desember 2014.

\section{Diskusi dan Sosialisasi}

Kegiatan ini dilakukan untuk memfasilitasi pembahasan permasalahan-permasalahan yang terjadi terkait dengan kegiatan pemberdayaan masyarakat sekaligus sebagai forum sosialisasi untuk kegiatan pengabdian masyarakat dengan tema pemberdayaan masyarakat desa Danasari. Kegiatan dan pembahasan tersebut dituangkan ke dalam bentuk diskusi yang terarah dengan peserta terbatas. Selanjutnya hasil diskusi ini menjadi materi yang dituangkan dalam bentuk Kegiatan Workshop dan pelatihan. Kegiatan ini dilakukan pada minggu pertama bulan Desember 2014.

Dari kegiatan diskusi ini maka dapat diketahui permasalahan yang dihadapi oleh masyarakat desa Danasari. Masalah yang membelenggu yang sangat dominan di mata masyarakat Danasari dan stakeholder setelah diadakan observasi dan dialog dengan masyarakat Asemdoyong diketahui sebagai berikut: 
a. Minimnya kegiatan Keagamaan untuk para ibu-ibu dan remaja.

b. Jarangnya Keluarga kumpul bersama karena tuntutan pekerjaan, sehingga rawan terjadi disharmonisasi keluarga.

c. Banyaknya lahan kosong yang belum dimanfaatkan secara maksimal.

d. Menurunnya kualitas lingkungan dan ekosistem.

Dari permasalahan diatas selanjutnya kegiatan Workshop dan pelatihan serta pemberian bibit tanaman jahe dijadikan sebagai suatu kegiatan untuk memberikan solusi untuk mengatasi permasalahan yang ada. Tema-tema yang terkait dengan penyelesaian masalah diatas dijadikan sebagai tema dalam kegiatan workshop dan pelatihan.

\section{Workshop dan Pelatihan}

Pelaksaaan kegiatan workshop dan pelatihan, kegiatan ini ditujukan untuk memberikan pengetahuan tentang Dakwah, pemberdayaan masyarakat,kepemimpinan, Semangat kerja/etos Kerja, kewirausahaan, menciptakan keluarga sakinah mawaddah wa rahmah, keterampilan budidaya tanaman jahe dan sukun. Hal ini untuk meningkatkan kapasitas dan pengetahuan masyarakat, berupa pengetahuan tentang dakwah, pemberdayaan masyarakat, motivasi berwirausaha, dan memanfaatkan lahan kosong dengan penanaman jahe atau sukun.

Kegiatan ini dilakukan di Aula Balai Desa desa Danasari yang diikuti oleh masyarakat desa Danasari terdiri dari Perangkat desa, Ketua RT dan RW, Kader PKK, Tokoh Masyarakat, Guru, Pedagang, Petani dan Buruh yang berjumlah 100 orang. Kegiatan workshop dan pelatihan ini dijadwalkan pada tanggal 30-31Desember mulai pukul 13.00 WIB sd 17.00 WIB. Adapun materi dan Narasumber pada Workshop dan pelatihan tersebut dapat dilihat dai tabel berikut:

\section{Tabel 4.5}

Susunan Acara Workshop dan Pelatihan

Dakwah Pemberdayanan Masyarakat Desa Danasari Kec. Pemalang Kab. Pemalang (Sosialisasi Dakwah, Pemberdayaan masyarakat, Kepemimpinan, Motovasi berwirausaha, Pemanfaatan lahan kosong, Pembentukan Keluarga Sakinah, Mawaddah wa Rahmah)

\begin{tabular}{|c|l|l|}
\hline \multicolumn{3}{|c|}{ Rabu, 30 Desember 2014 } \\
\hline Waktu & \multicolumn{1}{|c|}{ Acara } & Fasilitator/ Narasumber \\
\hline $13.00-13.30$ & Chek in, mengisidaftarhadir & Tim \\
\hline $13.30-14.00$ & Pembukaan & \\
\cline { 2 - 3 } & $\begin{array}{l}\text { 1. Pembacaan Ayat Suci Al } \\
\text { Qur'an }\end{array}$ & Muslihin, SE \\
\hline
\end{tabular}




\begin{tabular}{|c|c|c|}
\hline & 2. Laporan Panitia & $\begin{array}{ll}\text { Ketua Tim) } & \text { Hafied } \\
\text { Hasan, M.M } & \\
\end{array}$ \\
\hline & $\begin{array}{l}\text { 3. Sambutan Ketua STIT } \\
\text { Pemalang }\end{array}$ & Drs. Abdul Basit, M.Pd.I \\
\hline & 4. $\begin{array}{l}\text { Sambutan Kepala Desa } \\
\text { Danasari }\end{array}$ & H. Sanuri, S.Ip \\
\hline $14.00-15.00$ & $\begin{array}{l}\text { Sosialisasi Dakwah bilhal } \\
\text { dan Pemberdayaan Masyara- } \\
\text { kat Desa Danasari }\end{array}$ & $\begin{array}{l}\text { (Humas dan Ketua Lazis } \\
\text { STIT Pemalang) Purnama } \\
\text { Rozak, M.SI }\end{array}$ \\
\hline $15.00-16.00$ & $\begin{array}{l}\text { Kepemimpinan dalan } \\
\text { Masyarakat }\end{array}$ & $\begin{array}{l}\text { (Dosen STIT Pemalang) } \\
\text { Hafiedh Hasan, MM }\end{array}$ \\
\hline $16.00-17.00$ & Etos Kerja dalam Islam & $\begin{array}{lrr}\text { (Ketua } & \text { LPPM } & \text { STIT } \\
\text { Pemalang) } & \text { Srifariyati, } \\
\text { M.SI } & \end{array}$ \\
\hline \multicolumn{3}{|c|}{ Kamis, 31 Desember 2014} \\
\hline $13.00-14.00$ & $\begin{array}{l}\text { Kewirausahaan dan budi- } \\
\text { daya Tanaman Jahe }\end{array}$ & $\begin{array}{l}\text { (Ketua STIT Pemalang) } \\
\text { Drs. Abdul Basit, M.Pd.I }\end{array}$ \\
\hline 14.00 & Pemanfaatan Lahan Kosong & $\begin{array}{l}\text { (Dinas Pertanian dan } \\
\text { Kehutanan) Samhudi, S }\end{array}$ \\
\hline 15.00 & Budidaya Tanaman Sukun & $\begin{array}{l}\text { (Muballigh dan Dosen } \\
\text { STIT Pemalang) Drs. KH. } \\
\text { Masduki, M.Si }\end{array}$ \\
\hline \multirow[t]{2}{*}{$15.30-16.30$} & Pembentukan & (Kemenag Kab. Pemalang) \\
\hline & $\begin{array}{l}\text { Sakinah Mawaddah wa } \\
\text { Rahmah }\end{array}$ & \\
\hline $16.30-16.40$ & $\begin{array}{l}\text { Pemberian Bibit Tanaman } \\
\text { Jahe kepada masyarakat } \\
\text { secara simbolis }\end{array}$ & $\begin{array}{l}\text { Diterimakan Kepala Desa } \\
\text { Danasari }\end{array}$ \\
\hline $16.40-17.00$ & Penutupan & Tim \\
\hline
\end{tabular}

Pelatihan ini dilaksanakan dengan memberikan materi tentang Dakwah, pemberdayaan masyarakat,Kepemimpinan, Etos kerja, motivasi berwirausaha, Pemanfaatan lahan kosong, budidaya tanaman jahe dan sukun, dan pembentukan keluarga sakinah mawaddah wa rahmah. Dari pelatihan ini, peserta bisa mempunyai pengetahuan tentang Dakwah bil alhal, pemberdayaan Masyarakat, menjadi pemimpin yang baik, motivasi berwirausaha, cara memanfaatkan lahan kosong, membetuk keluarga yang sakinah ma waddah wa rahmah, dan memberikan contoh untuk berwirausaha dan memanfaatkan lahan kosong dengan bertani jahe atau sukun. Dengan demikian, peserta mendapatkatkan solusi dari 
permasalahan yang ada yaitu, minimnya kegiatan Keagamaan untuk para ibu-ibu dan remaja, jarangnya keluarga kumpul bersama karena tuntutan pekerjaan, sehingga rawan terjadi disharmonisasi keluarga, masih banyaknya lahan kosong yang belum dimanfaatkan secara maksimal.

Pada tataran implementatif, selanjutnya peserta dapat melakukan kegiatan dakwah di masyarakat menurut kemampuannya, menjaga hubungan yang harmonis dalam keluarganya, dan dapat memanfaatkan lahan-lahan kosong.

Kegiatan Workshop dilanjutkan dengan pemberian 500 Bibit Tanaman Jahe dari Tim Pengabdian Masyarakat kepada masyarakat desa Danasari melalui Bapak Kepala Desa. Pemberian Bibit Tanaman Jahe pada kegiatan pengabdian ini dan fasilitasi konsultasi tanaman Jahe merupakan bukti nyata dalam usaha untuk memanfaatkan lahan kosong yang selanjutnya dapat meningkatkan pendapatan masyarakat desa Danasari.

Kegiatan pengabdian masyarakat dengan program dakwah melalui pemberdayaan masyarakat desa Danasari ditutup dengan evaluasi program dan pelaporan kegiatan.

\section{G. Analisis Program Dakwah Melalui Pemberdayaan Masyarakat Desa Danasari}

Kegiatan workshop dan pelatihan ini adalah sebagai upaya pemberdayaan masyarakat dengan memberikan pengetahuan, wawasan dan keterampilan kepada masyarakat untuk memberikan solusi tentang permasalahan yang ada setelah diadakan diskusi dan studi awal. Adapun permasalahan dan Solusi yang diupayakan dalam kegiatan pemberdayaan masyarakat adalah sebagai berikut:

Tabel 4.7

Solusi yang diupayakan dalam Kegiatan Pemberdayaan Masyarakat Desa Danasari

\begin{tabular}{|l|l|l|}
\hline No & \multicolumn{1}{|c|}{ Permasalahan } & \multicolumn{1}{c|}{ Solusi } \\
\hline 1 & $\begin{array}{l}\text { Minimnya kegiatan Ke- } \\
\text { agamaan untuk para ibu-ibu } \\
\text { dan remaja. }\end{array}$ & $\begin{array}{l}\text { Memberikan wawasan melalui } \\
\text { workshop dan pelatihan tentang } \\
\text { dakwah, pemberdayaan } \\
\text { Masyarakat, dan kepemimpinan }\end{array}$ \\
\hline 2 & $\begin{array}{l}\text { Jarangnya Keluarga kumpul } \\
\text { bersama karena tuntutan } \\
\text { pekerjaan, sehingga rawan } \\
\text { terjadi disharmonisasi } \\
\text { keluarga. }\end{array}$ & $\begin{array}{l}\text { Memberikan wawasan melalui } \\
\text { workshop dan pelatihan tentang } \\
\text { Keluarga Sakinah Mawaddah wa } \\
\text { Rahmah }\end{array}$ \\
\hline
\end{tabular}




\begin{tabular}{|l|l|l|}
\hline 3. & $\begin{array}{l}\text { Banyaknya lahan kosong } \\
\text { yang belum dimanfaatkan } \\
\text { secara maksimal. }\end{array}$ & $\begin{array}{l}\text { Memberikan pelatihan-pelatihan } \\
\text { tentang pemanfaatan lahan } \\
\text { kosong melalui budidaya } \\
\text { Tanaman Jahe dan sukun. }\end{array}$ \\
\hline 4. & $\begin{array}{l}\text { Minimnya fasilitas pendidi- } \\
\text { kan dan keterampilan } \\
\text { penunjang bagi peningkatan } \\
\text { life skills }\end{array}$ & $\begin{array}{l}\text { Memberikan wawasan tentang } \\
\text { kewirausahaan }\end{array}$ \\
\hline 5 & $\begin{array}{l}\text { Menurunna kualitas } \\
\text { lingkungan dan ekosistem }\end{array}$ & $\begin{array}{l}\text { Memberikan wawasan kepada } \\
\text { masyarakat tentang pemberda- } \\
\text { yaan masyarakat termasuk } \\
\text { menjaga lingkungan dan } \\
\text { ekosistem laut dengan } \\
\text { menggunakan jaring sesuai } \\
\text { dengan aturan ketika mengkap }\end{array}$ \\
\hline
\end{tabular}

Kegiatan workshop dan pelatihan ini telah mengusahakan nara sumber sesuai dengan bidang keahlinnya. Untuk lebih mendekatkan pemerintah daerah, kepada masyarakat, maka nara sumber dalam kegiatan workshop dan pelatihan ini melibatkan dinas-dinas terkait seperti Kementrian Agama, dan Dinas Pertanian dan Perhutanan kabupaten Pemalang. Selain itu juga melibatkan instansi dan pihak terkait (stakeholder) yang berhubungan dengan Dakwah dan upaya pemberdayaan dan pelayanan kesejahteraan masyarakat, baik dari lembaga pemerintah, Perguruan tinggi, Tokoh masyarakat dan masyarakat danasari pada umumnya.

Kelompok sasaran workshop dan pelatihan dalam upaya pemberdayaan masyarakat desa Danasari ini terdiri dari Perangkat Desa, Ketua RT dan RW, Kader PKK, Tokoh Masyarakat, Guru, Pedagang, Petani dan Buruh yang berjumlah 100 orang. Kegiatan workshop dan pelatihan ini mencakup semua lapisan masyarakat, ini diharapkan bahwa program pemberdayaan ini akan dapt berjalan bersama-sama di masyarakat Danasari khususnya dalam bidang keagamaan, wirausaha dan pemanfaatan lahan kosong.

Hasil yang diperoleh dari kegiatan workshop dan pelatihan ini adalah masyarakat memperoleh pengetahuan tentang dakwah, pemberdayaan masyarakat, Semangat kerja/etos Kerja, kewirausahaan, menciptakan keluarga sakinah mawaddah wa rahmah, keterampilan budidaya tanaman jahe dan sukun. Hal ini untuk meningkatkan kapasitas dan pengetahuan masyarakat, berupa pengetahuan tentang Dakwah, pemberdayaan 
masyarakat, motivasi berwirausaha, dan memanfaatkan lahan kosong dengan penanaman jahe atau sukun.

Kegiatan Bantuan tanaman jahe merupakan kegiatan stimulan dalam rangka pemanfaatan lahan kosong. Tim juga menyediakan tenaga sebagai tempat konsultasi dalam pemeliharaan budidaya sukun dan jahe yang bertempat di Kampus STIT Pemalang.

\section{H. Kesimpulan}

Dakwah Pemberdayaan Masyarakat Desa Danasari Kecamatan Pemalang Kabupaten Pemalangini masih perlu dilanjutkan dan ditingkatkan sampai masyarakat dapat mandiri. Dengan prinsip Khairunnaas anfa'uhum linnaas. (Sebaik-baik manusia adalah manusia yang bermanfaat bagi manusia lain), maka apapun ilmu pengetahuan dan keterampilan yang kita miliki akan lebih jauh bermanfaat jika kita salurkan kepada sesama. Hal ini kita bisa kita terapkan lewat pemberdayaan masyarakat di lingkungan sekitar. Bentuk pemberdayaan disesuaikan dengan kondisi masyarakat setempat dan analisis solusi permasalahan secara tepat.

\section{DAFTAR PUSTAKA}

Kusnadi, Strategi Hidup Masyarakat Nelayan, Yogyakarta : LkiS, 2007

Sulthon, M, Menjawab Tantangan Zaman: Disain Ilmu Dakwah, Kajian Ontologis, Epistemologis, dan Aksiologis, Pustakan Pelajar, Jogyakarta: 2003

Surochiem, Dimensi-dimensi Penting Monitoring Pelaksanaan Program Pemberdayaan dan Partisipasi pada Masyarakat Pesisir. Jurnal, 2001

Tasmara,Toto, Komunikasi Dakwah, Jakarta: Gaya Media Pratama, 1977

Wahyono, Ari. dkk. Pemberdayaan Masyarakat Nelayan, Yogyakarta: Media Pressindo, 2001 